\title{
The Effects of Ligitation Risk and Investment Opportunity Set Affected by Good Corporate Governance on the Company's Earning Quality
}

\author{
Adelina Suryati \\ Student Doctoral Program Faculty of Economics and Business, University of Trisakti, Indonesia \\ Lecturer in Accounting Departemen, Faculty of Economic Bhayangkara Jakarta Raya, Indonesia
}

Etty Murwaningsari

Faculty of Economic and Business, Trisakti University, Jalan Kyai Tapa No 1, Grogol, Jakarta, Indonesia \begin{abstract}
Ligitation Risk and Investment Opportunity Set (IOS) are management activities in a company that can affect the earnings quality. Therefore, the two activities must be regulated properly. This study will analyze litigation risk and IOS that are intervened by well-organized corporate governance with a moderation method on the earnings quality. The data used in this study is a report of company in manufacturing in 2013 to 2016 which are included in the Indonesia Stock Exchange list using purposive sampling. The variables used consisted of earnings quality $(\mathrm{KL})$, litigation risk (RL), investment opportunity set (IOS) and company growth (COGH). The data was tested using multiple regression and moderation methods. The results showed that earnings quality was significantly influenced by investment opportunity set and control company growth variables, while the magnitude of earnings quality was not affected by litigation risk, litigation risk and investment opportunity set moderated by good corporate governance. The board of commissioners, corporate governance factors that moderate the risk of litigation and investment opportunity set in this study can change the value of earnings quality but are not able to have a significant influence.
\end{abstract}

Keywords: Corporate Governance, Earning Quality, Litigation Risk, Invesment Opportunity Set

DOI: $10.7176 /$ RJFA/10-22-07

Publication date: November $30^{\text {th }} 2019$

\section{Introduction}

In this era of globalization, a company must show exceptional performance that shows the ability to compete and survive (going concern) in its business to stakeholders. One source of information that is used by stakeholders in assessing company performance is the financial statements in which there are reports related to company profits (Naula Oktaviani, Nur, \& Ratnawati, 2015). Earnings income at each company is expected to be a truly real information, in this case the profits generated by a company can be said to have different qualities (Murwaningsari, 2009). Earnings quality is profit that correctly and accurately describes the company's operational profitability (Wati \& Putra, 2017). According to Schipper and Vincent (2003) in Sutopo (2009), that earnings quality is grouped and measured in various ways, among others (1) based on the time sequence which includes: tenacity, predictive ability, and ability to variation (2) based on earnings and cash related accruals include the ratio of cash and profit, changes in the value of accruals, abnormal, and estimation of cash-accrual relationship. Earnings quality can be based on a Qualitative Conceptual Conceptual Framework (Financial Accounting Standards Board, FASB, 1978) and can also be based on implementation decisions (Wati \& Putra, 2017). To be sure, the quality of earnings is a concern for investors and accounting policy makers and government. Many management activities that affect earnings quality are related to the number of audit committees (Bilal, Chen, \& Komal, 2018), he role of the efficiency of the stock exchange (Hassan, 2017), setting the price of earnings to economic conditions (Zhang, 2018), the bank's financial structure (Jin, Kanagaretnam, \& Liu, 2018), global financial crisis (L. Chen, Krishnan, \& Yu, 2018), cash holdings (Farinha, Mateus, \& Soares, 2018), litigation risk (Aristiani \& Purwanto, 2015; Awalia \& Daljono, 2014; Peda \& Vinnari, 2019) dan IOS (Lee, Wang, Chiu, \& Tien, 2018; Wulandari, 2018). This research will focus on analyzing the effect of litigation risk and investment opportunity on earnings quality.

Litigation risk is a management activity that can affect the actions of managers in running the company. This will affect the earnings quality disclosed (Aristiani \& Purwanto, 2015). Litigation risks that occur in management activities include litigation risks to company costs in 361 companies in 16 countries (Arena \& Ferris, 2018), geographical position of companies and distant investors (Mazur, Salganik-Shoshan, Walker, \& Wang, 2018) and who is entitled to the company's cash (Nguyen, Phan, \& Sun, 2018). Another management activity that affects earnings quality is the investment opportunity set (IOS). Gaver and Gaver (1993) state that IOS is a company opportunity to grow in company value, the amount of IOS depends on company spending that has been designed by management for the future, which at this time the investment is expected to produce more results in the future (Wulandari, 2018). Thus, a company that has a high IOS value usually has a high 
discretionary accrual value which also affects the earnings quality of corporate (Wulandari, 2018). In US industrial companies during 1988-2015, companies that have managers with superior capabilities can obtain more economic benefits through better IOS (Lee et al., 2018). Another thing, in Indonesian manufacturing companies in 2013-2014 which are entered on the Stock Exchange list, managerial ownership can strengthen the effect of IOS which is determined conservatively (Murwaningsari \& Rachmawati, 2017) so that it affects earnings quality indirectly. So that the risk of litigation and IOS does not affect the condition of earnings quality that is not good, good corporate governance must be carried out. The methode is called good corporate governance.

Corporate governance is policies, the customs, sequence of processes, institutions and laws that can direct and control the company. Companies use corporate governance to improve company operations and performance, sales, strategies to achieve goals, financial predictions, product development, human resource management, company development strategies and procurement procedures (Emmanuel \& Toyin, 2019). Good corporate governance that is applied will produce more profits, increase the value of sales and the use of smaller capital in a company (Emmanuel \& Toyin, 2019). Good corporate governance has been implemented by public companies registered in Malaysia (Janggu, Darus, Zain, \& Sawani, 2014), chemical, pharmaceutical and consumer goods companies (Sofia \& Murwaningsari, 2019), manufacturing companies in Nigeria (Emmanuel \& Toyin, 2019; Omokhudu, Stephen, \& (Ph.D), 2013) and the company Banja Luka of the Republic of Srpska listed on the Stock Exchange (Todorovic, 2013). Based on this research, good corporate governance must be done by companies in order to increase the earnings quality of corporate.

This research will analyze the effects of litigation and IOS risk on the company's earnings quality. The data used are manufacturing companies as in several previous studies (Emmanuel \& Toyin, 2019; Murwaningsari \& Rachmawati, 2017; Omokhudu et al., 2013; Sofia \& Murwaningsari, 2019). The sample used was manufacturing companies in Indonesia in 2013-2016 which were entered on the Stock Exchange list. In this research, the risk of litigation and IOS in this study will be moderated by corporate governance on earnings quality such as research on French companies that analyze the impact of corporate governance on the performance of short-term acquisitions (Thraya, Lichy, Louizi, \& Rzem, 2019), MNE Europe's subsidiary analyze the depth and extent of the external knowledge and information search for the transfer of knowledge of its subsidiary (Gölgeci, Ferraris, Arslan, \& Tarba, 2019) and the Canadian International Development Research Center (IDRC) which analyzes the organization's capacity for corporate governance (Mustapa, Ghazali, \& Mohamad, 2014). The results of the data obtained will be analyzed how much influence the corporate governance that moderates the risk of litigation and IOS on manufacturing companies in Indonesia which are entered on the Stock Exchange list.

\section{Literature Review and Hypothesis}

\subsection{Litigation Risk and Earnings Quality}

Litigation as a factor that comes from outside the company due to the existence of one of the injured parties for actions taken by another party that is not in accordance with the agreement. This litigation is one of the risks inherent in the company that allows the occurrence of litigation threats by interested parties (creditors, investors, regulators) that are harmed by the company. The risk of litigation can affect the actions of managers in running the company. This will affect the earnings quality disclosed (Aristiani \& Purwanto, 2015). The manager's action taken in relation to litigation risk is to arrange information between bad news and good news related to positive earnings reports, profits and company staff activities (Bliss, Partnoy, \& Furchtgott, 2017). Skinner (1994) states managers who fear legal responsibility will give bad news warnings voluntarily. However, managers try to reduce the risk of litigation (Bliss et al., 2017). Therefore, litigation risk tends to have strong implications on a company's ability to raise funds and invest in opportunities to get a clean value (Arena, 2017). Litigation risk is significantly positively related to discretionary accruals in which company managers try to cover financial statements by manipulating reporting numbers with the aim of making the best quality of financial reporting (Awalia et al., 2014). This is in accordance with agency theory related to corporate governance. Agency theory developed by Michael Johnson in Achmad Daniri, 2006 views that company management as an "agent" for shareholders, will act with awareness for their own interests (Murwaningsari, 2009). Agency problems arise, including if the management (agent) does not own the company's ordinary shares. With this condition, agents do not try to maximize company profits and agents try to take advantage of the burden borne by shareholders, in the form of increased wealth and satisfaction and company facilities, including manipulating the company's financial statements to get prizes or bonuses that are calculated based on achieving financial numbers that are presented in the Financial Statements. Agency theory wants to solve problems arising from agency relationships, namely when shareholders cannot know for sure whether the agent has acted appropriately, and when shareholders have a different view of the agent regarding risk (Kovermann \& Velte, 2019; Sofia \& Murwaningsari, 2019). Agency theory stipulates that opposing interests (shareholders) and managers (agents) can trigger conflict and will disrupt the smooth running of the company (Rodriguez-Fernandez, 2016). The separation between the agent and the shareholders contained in the agency theory results in the risk of conflict that can affect earnings quality. 
Management tends to prepare earnings reports in accordance with specific objectives and interests and not in the interests of shareholders. Therefore, a control mechanism is needed so that it can align the differences of interests between the two parties (Wati \& Putra, 2017). This happened to several manufacturing companies in Indonesia in 2010-2012 listed on the stock exchange where discretionary accruals occurred (Awalia \& Daljono, 2014), Estonian public-private water companies showed that there was a debate over public-private profit and the highest authority which decides this with the aim of seeking excess profits (Peda \& Vinnari, 2019) making it vulnerable to intervention and litigation from the community and government (Nafisah \& Meiranto, 2017). Therefore, the first hypothesis in this study is:

H1: Litigation risk negatively affects earnings quality

\subsection{Investment Oppurtinity Set (IOS) and Earnings Quality}

Investment is an activity to support the company's operational activities which will later benefit the company. To achieve efficiency, investments must be made in accordance with needs. Investment will be efficient if the company avoids overinvestment (lack of capital) and underinvestment (excess capital). Managers must be able to read the right investment opportunities for the company (Aristiani \& Purwanto, 2015). According to Myers (1997) and Marinda (2014), IOS is one form of investment decision that combines owned assets with the possibility of investing in the future by linking positively the present value (NPV) that affects the company's credibility (Murwaningsari \& Rachmawati, 2017). Kallapur and Trombley (2001) in Murwaningsari (2017) stated that the company's ability is shown by the company's growth to increase the value of the company and IOS is an option to invest which is expected to have a positive NPV. The policy on IOS affects aspects of corporate finance, capital structure, corporate debt contracts, profit-related policies, compensation contracts, and accounting policies (Murwaningsari \& Rachmawati, 2017). Gaver and Gaver (1993) state that IOS is a company opportunity to grow in company value, the amount of which depends on the company's expenses that have been designed by management for the future, which at this time the investment is expected to produce more results in the future (Wulandari, 2018). Capital allocation decisions related to corporate investment are internal capital allocations which are investment opportunities in companies and external capital allocations where capital comes from providers of capital. Much of the previous research has focused on the allocation of external capital where the effects of this study provide asymmetrical or unbalanced information when there are conflicts of interest between providers of capital and managers (Ferracuti \& Stubben, 2019). Because of agency conflict, a company that has a high IOS value is likely to have a high discretionary accrual value that also affects the earnings quality of corporate (Wulandari, 2018). A study of US industrial companies during 1988-2015 revealed that companies with managers with superior capabilities could obtain more economic benefits through better IOS (Lee et al., 2018). Observation of manufacturing companies in Indonesia in 2013-2014 entered on the Stock Exchange list shows that managerial ownership can strengthen the effect of IOS which is determined conservatively (Murwaningsari \& Rachmawati, 2017) which also affects earnings quality indirectly. Myers (1977) stated in Lee (2018) that the value of investment and assets opportunities are the market value of a company, which cannot be observed and is dependent on future investments. Investment opportunities for market conditions consist of book value, equity, the ratio of capital expenditure to the net value of the company's operating assets and the ratio of prices and prices. Adam and Goyal (2008) show that one proxy related to IOS is the market to book ratio and this measure is widely used in various studies. One proxy that is often used to calculate IOS is Proxi Tobin's. This proxy contains the highest information content related to investment opportunities. The main thing Tobin's is to improve IOS by considering physical, non-physical assets where these assets are increasingly important in improving services and high-tech industries. This proxy has been proven by Peters and Taylor (2017 where other proxies are better. This proxy proves that companies with superior managers make IOS higher, resource management more efficient and the implementation of new projects can be better (Lee et al., 2018) so that it can improve the quality of corporate earnings. Therefore, the second hypothesis in this study is:

H2: IOS has a positive effect on earnings quality

\subsection{Corporate Governance, Litigation Risk and IOS.}

Cadbury (2000) argues that the separation of control, direction and control of the company between business owners and managers raises a management system called corporate governance. (Habib \& Hasan, 2019; Rodriguez-Fernandez, 2016). Agency theory provides reasons for possible conflicts that can develop between principals (shareholders) and agents (management). Navas López and Guerras Martín (2004) in Rodriques (2016) stated that corporate governance is a mechanism that monitors conflicts between business owners and managers in company management (Rodriguez-Fernandez, 2016). According to Cuervo (2002), the part of management that is very instrumental in disciplining and giving advice to management is the board of directors. (Rodriguez-Fernandez, 2016). The board of directors directs management to make the most appropriate decisions for the organization. Good corporate governance is an absolute requirement for the industrial world to be able to develop well and healthily so as to realize good stakeholder value where public trust and the 
international world can be fulfilled (Murwaningsari, 2009). Aspects affecting corporate governance include intensive equality between owners and managers, board composition, capital market control, audit activities, management policies, ownership structures, stakeholder desires and relations with government (Kovermann \& Velte, 2019). The implementation of good corporate governance can increase profits such as increasing the value of sales and the use of smaller capital in a company (Emmanuel \& Toyin, 2019). The terms that occur in corporate governance include bad corporate governance, good, local and company. Pacy Sifuna (2012) the mechanism of duties and rights in directing and controlling a company is a corporate governance company. (Iqbal \& Kakakhel, 2016). According to Mashayekhi and Bazaz (2010), the effectiveness of corporate governance practices in reducing conflicts between company owners and managers is a measure of the quality of good corporate mechanisms. Muid (2009) states that aspects of corporate governance that positively affect earnings quality are managerial ownership and institutional ownership, whereas the board of commissioners and audit committee have no effect. Tuwentina (2014) found that corporate governance measured by the Corporate Governance Perception Index (CGPI) had no effect on earnings quality (Wati \& Putra, 2017). Good corporate governance has been implemented in 100 publicly listed companies in Malaysia where company size, professionalism and the establishment of a board of commissioners have a significant impact on corporate sustainability (Janggu et al., 2014), chemical, pharmaceutical, and consumer goods companies where capital, ownership structure, and information asymmetry which are factors of corporate governance are proven to significantly affect earnings management (Sofia \& Murwaningsari, 2019), manufacturing companies in Nigeria have shown that increasing ownership of chief executives significantly increases organizational performance while increasing director's share ownership significantly causes a decrease organizational performance (Omokhudu et al., 2013), manufacturing companies in Nigeria show heterogeneity effects in all existing Nigerian manufacturing companies especially board size and gender inequality on the board negatively impacting the financial performance of companies with significant spirit of earnings quality (Emmanuel \& Toyin, 2019), 19 companies in Banja Luka of the Republic of Srpska show that companies with lower implementation rates and not complying with corporate governance principles result in lower net profit margins compared to companies from Austria (Todorovic, 2013). Based on this research, good corporate governance must be carried out by the company in order to improve the quality of the company's profits, including maintaining the risk of litigation and creating an optimal IOS. Therefore, the third and fourth hypotheses in this study are:

H3: The negative effect of litigation risk on earnings quality can be strengthened to be positive by good corporate governance.

H4: The positive influence of IOS on earnings quality is strengthened by good corporate governance

\section{Methedology of Research}

3.1 Selection of Sample

Secondary data in this researh came from 544 company of manufacturing in Indonesia in 2013 - 2016 related to financial statements contained in Stock Exchange of Indonesia. Of the total reports, 314 of the financial statements of manufacturing companies were sampled. The purposive sampling method is used to select samples to maintain data homogeneity. The sample criteria taken are as follows (Aristiani \& Purwanto, 2015).

(1) Publish financial statements in rupiah and be entered on the Indonesia Stock Exchange (IDX) list;

(2) Included in the manufacturing industry group in Indonesia.

(3) Publish annual and financial reports on December 31 during the observation period;

(4) Has the data needed to support research; and

(5) The company's profit is not negative or zero so that it can be analyzed properly.

\subsection{Operational Variable}

\subsubsection{Variable dependent - Earnings Quality}

Earnings quality (KL) is the dependent variable of this research. Leuz et al. (2003) measures earnings quality with indicators of income variability that are the same as standard operating income deviations divided by standard cash flow deviations from operations. According to Barton and Simko (2002), a measure of earnings quality is unexpected income which is the ratio of the net initial balance of operating assets relative to sales Penman (2001) measure earnings quality based on the ratio of operating cash flows divided by net income (Abdelghany, 2005; Naula Oktaviani et al., 2015; Septiyani, Rasyid, \& Tobing, 2017). Based on the data obtained, this research uses the opinion of Penman (2001) in calculating earnings quality.

3.2.2 Variable independent - Ligitation Risk dan IOS

The risk of litigation and IOS are the independent variables of this research. The definition of litigation risk is the default risk of a company that has the possibility of a litigation threat by a party that feels disadvantaged related to the company's interests). According to Juanda (2007), in Herawati and Sinarwati, (2012), litigation risk is measured by the indicator of the ratio of total debt divided by total equity. Investment opportunity set is 
measured by an indicator of market value ratio divided by total equity (Lee et al., 2018). Market value is obtained from the number of shares at times the closing stock price. The choice of proxy is because it can reflect the amount of return from existing activities and the expected investment in the future exceeds the return of the desired equity.

\subsubsection{Variable moderation - Corporate Governance}

The moderating variable used is corporate governance. Indicators of corporate governance are institutional ownership, the board of directors, the board of directors, managerial ownership, and the audit committee. Institutional ownership is the percentage of the number of shares owned by an institutional party from all of the company's outstanding shares. Managerial ownership is the percentage of the number of shares owned by management from all of the company's outstanding shares. The board of commissioners consists of the number of independent board members. The board of directors is the number of members of the board of directors. Audit committee is the number of audit committee members in the company (Naula Oktaviani et al., 2015). In this research, the board of commissioners measured by the number of independent commissioners to the number of board of commissioners is used as an indicator of the value of corporate governance.

3.2.4 Control variable - Company Growth

Control variables are additional variables that can affect the hypothetical framework relationships that are made (S. Chen, Bu, Wu, \& Liang, 2014; Gölgeci et al., 2019). This research will use the control variable in this research is company growth with the indicator being sales of $t$ or current year in less sales last year divided by last year's sales at one hundred percent.

\subsection{Data analysis}

In this research, the variables that have been obtained are tested using Moderated Regression Analyze (MRA) where there is an element of interaction, namely the multiplication of two or more variables in the regression equation as is done in French companies that analyzed the impact of corporate governance on the performance of short-term corporate acquisitions (Thraya et al., 2019), MNE European subsidiary which analyzes the depth and extent of the external knowledge and information search to the transfer of knowledge of its subsidiary (Gölgeci et al., 2019) and the Canadian International Development Research Center (IDRC) which analyzes the organization's capacity for corporate governance (Mustapa et al., 2014). The basic equation for calculating earnings quality is (Dechow, Ge, \& Schrand, 2010):

$$
R E=\text { Function of }(X)+e
$$

Where $\mathrm{RE}=$ reporting earnings / earnings quality, $\mathrm{X}=$ independent and control output variables and $\mathrm{e}=$ errors caused by the accounting system.

With the moderation of corporate governance on litigation and IOS risk, the earnings quality equation combined with the MRA equation model in this research is as follows.

$$
K L=\alpha+\beta_{1} R L+\beta_{2} I O S+\beta_{3} C G+\beta_{4} R L: C G+\beta_{5} I O 5: C G+\beta_{6} C O G H+e
$$

Where KL $=$ Profit Quality, $\alpha=$ constant, $\beta_{1}, \beta_{2}, \beta_{3}, \beta_{4}, \beta_{5}, \beta_{6}=$ coefficient, RL = Litigation Risk, IOS = investment opportunity set, $\mathrm{CG}=$ Corporate Governance, $\mathrm{COGH}=$ Company Growth . dan e = error.

\section{Result and Analysis}

4.1 Descriptive statistics

4.1.1 Sampel Description

During 2013 - 2016 there were 544 company of manufacturing in Indonesia Stock Exchange list. The sample description of the company used in this research is as follows.

Table 2. Summary of Obtaining Samples

\begin{tabular}{|l|c|}
\hline \multicolumn{1}{|c|}{ Criteria } & Total \\
\hline $\begin{array}{l}\text { Manufacturing companies entered on the IDX during 2013 - } \\
2016 \text { list }\end{array}$ & 544 \\
\hline $\begin{array}{l}\text { Companies that do not publish financial statements or annual } \\
\text { reports in full }\end{array}$ & 135 \\
\hline Companies that do not issue financial reports use the rupiah & 60 \\
\hline Companies with zero or negative profits & 35 \\
\hline The final number of samples used in the research & 314 \\
\hline
\end{tabular}

Table 2 shows the sample selection from the population of the sample selection process used from 544 manufacturing companies in Indonesia in 2013-2016 listed on the Indonesia Stock Exchange after checking related financial statements, corporate governance components, the use of currency and profits above zero, obtained 314 companies used as samples . 


\subsubsection{Variabel Desciption}

Description of the variables obtained in this research are as follows.

Table 3. Variabel Description

\begin{tabular}{|l|c|c|c|c|c|}
\hline Variabel & N & Min & Max & Mean & Std. Deviasi \\
\hline RL & 314 & -8.33 & 13.80 & 1.7845 & 3.67365 \\
\hline IOS & 314 & -12.86 & 21.68 & 5.2433 & 6.68016 \\
\hline KL & 314 & -3.00 & 3.96 & 0.3432 & 1.19136 \\
\hline COGH & 314 & 11.34 & 30.63 & 22.4150 & 5.36968 \\
\hline
\end{tabular}

Table 3 shows a description of the research variables consisting of litigation risk (RL), investment opportunity set (IOS), earnings quality (KL) and Company Growth (COGH). The number of samples used (N) is 314 companies. Judging from the RL variable, the lowest (minimum) RL of -8.33 occurred in Andalan, Tbk (ITMA) companies in 2015 while the highest (maximum) RL of 13.8 occurred in Andalan Energy Source companies, Tbk (ITMA) in 2014. The average magnitude of RL from 2013 to 2016 was 1.7845 , with a standard deviation of 3.67365. Judging from the IOS variable, the lowest (minimum) IOS value of -12.86 occurred in the Kimia Farma (PERSERO), Tbk (KAEF) company in 2015 while the highest (maximum) IOS value of 21.68 which occurred at Astra International companies, Tbk (ASII) in 2013. The average IOS value from 2013 to 2016 was 5.2433 , with a standard deviation of 6.68016. Seen from the KL variable, the lowest (minimum) KL value of -3.00 occurred in Kimia Farma (PERSERO), Tbk (KAEF) companies in 2015 while the highest (maximum) KL value of 3.96 occurred in the Energy Sources company Andalan, Tbk (ITMA in 2015. The average KL magnitude from 2013 to 2016 was 0.3432, with a standard deviation of 1.19136. Seen from the COGH variable, the lowest (minimum) COGH value was 11.34 which occurred in companies Toba Pulp Lestari, Tbk (INRU) in 2016 while the highest (maximum) COGH value of 30.63 occurred in the Indomobil Sukses Internasional, Tbk (IMAS) company in 2013. The average COGH from 2013 to 20132016 of 22.4150, with a standard deviation of 5.36968 .

\subsection{Variabel Testing}

The results of the test variables that exist in this research by using assumption testing and hypothesis testing can be seen in table 4.

Table 4. Assumptions and Hypothesis Test Results

\begin{tabular}{|l|c|c|c|c|c|}
\hline \multirow{2}{*}{ Variabel } & \multirow{2}{*}{ Prediction } & \multirow{2}{*}{ Coefficients } & \multirow{2}{*}{ Sig } & \multicolumn{2}{c|}{ Collinearity } \\
\cline { 5 - 6 } & & & & Tolerance & VIF \\
\hline $\mathrm{C}$ & & & 0,000 & & \\
\hline $\mathrm{RL}$ & - & 0,387 & 0.660 & .992 & 1.009 \\
\hline $\mathrm{IOS}$ & + & 0.346 & 0.001 & .268 & 3.738 \\
\hline $\mathrm{COGH}$ & + & 0,025 & 0,000 & .269 & 3.724 \\
\hline $\mathrm{RL} * \mathrm{CG}$ & + & 0,024 & 0.668 & .988 & 1.012 \\
\hline $\mathrm{IOS} * \mathrm{CG}$ & + & 0,019 & 0.732 & .988 & 1.012 \\
\hline
\end{tabular}

\begin{tabular}{|l|l|c|l|l|l|}
\hline $\mathrm{R}^{2}$ & & 0.041 & & & \\
\hline Adj $\mathrm{R}^{2}$ & & 0.031 & & & \\
\hline F-Statistic & & 4.380 & & & \\
\hline Prob (F-Statistic) & & 0.000 & & & \\
\hline Asymp. Sig. (2-tailed) & & 0.005 & & & \\
\hline Durbin Watson & & 1.934 & & & \\
\hline Observation & & 314 & & & \\
\hline
\end{tabular}

Significant at the $5 \%$ level

Note: RL : Litigation Risk, IOS : Investment Opportunity Set, COGH : Company Growth, CG : Corporate

Governance

4.2.1 Assumption test

Data testing conducted before the linear regression and MRA tests are normality test, multicollinearity test and heterokedacity test. Normalization test produces a graph of the output histogram and P-P Plot Regression Standarized residual from existing data. In the output histogram, the histogram generated from existing data is in the form of symmetrical / bell shape, the highest frequency data is in the middle and decreases and gradually and symmetrically on both sides, which means the data is normally distributed. At the P-Plot output, the position of the points on the P-Plot are close to many of the diagonals axis showing normally distributed data, so the data is normally distributed. Multicollinearity testing is performed on all independent variables, namely litigation risk, IOS and company growth control variables which can be seen in table 4. The test results show the multicollinearity test of existing data has a tolerance point $>0.10$, from 0.269 to 3.724 and VIF point $<10$ which 
is 1.009 to 3.738 . These results indicate the testing of independent variables in this research do not show symptoms of multicollinearity and and the correlation between variables is weak so that the variable is truly independent. In the heteroscedasticity test, the results of testing existing data generated scatterplot charts. Heteroscedasticity test results show that many points are above and below the number 0 on the $\mathrm{Y}$ axis and are spread evenly, then there is no heterokedastisitas.

4.2.2 Hypotesis test

Hypothesis testing results can be seen in table 4. Determination testing shows the coefficient of determination of existing data of 0.031 . The dependent variable that is earnings quality can be predicted using variations in the independent variable litigation risk and investment opportunity set which is also moderated by corporate governance and control company growth variable with a value of $3.1 \%$, while the remaining $96.9 \%$ is predicted by other variables. To test the hypothesis that has been made, the test uses a partial regression method. In the litigation risk hypothesis and earnings quality tested by the partial regression test method the significance value of this hypothesis is 0.660 and the coefficient point -0.387 . The earning quality hypothesis that is influenced by IOS shows the significance value of this hypothesis of 0.001 and the coefficient point of 0.346 . In the earnings quality hypothesis that is influenced by litigation risk moderated by corporate governance shows the significance value of this hypothesis is 0.668 and the coefficient point is 0.024 . In the earnings quality hypothesis influenced by IOS which is moderated by corporate governance shows the significance value of this hypothesis is 0.732 and the coefficient point is 0.019 . In addition, earnings quality influenced by COGH showed a significance value of 0,000 and a coefficient point of 0.025 .

\section{Discussion}

5.1 Litigation risk hypothesis on earnings quality

The hypothesis related to litigation risk and earnings quality is that litigation risk negatively affects earnings quality. The test shows that litigation risk has a negative effect on earnings quality where each increase of 1 (one) unit of opportunity risk value will result in a decrease in quality of - 0.387 units. This means that litigation risk can reduce the quality of profits obtained by the company. Penman (2001) states an indicator of earnings quality is the ratio of operating cash flows divided by net income (Abdelghany, 2005; Naula Oktaviani et al., 2015; Septiyani et al., 2017). The smaller the ratio, the greater the quality of the profit (Abdelghany, 2005). Litigation risk value is obtained from the ratio of total number of debt divided by total number of equity. Therefore, litigation risk negatively affects earnings quality because the total debt is calculated negatively. Litigation risk values can be associated with conflicts of interest between shareholders and managers where if conflicting interests can conflict that interferes with the smooth performance of the company (RodriguezFernandez, 2016). This affects the earnings quality reported (Wati \& Putra, 2017) where management parties who have certain interests will tend to make earnings reports that are in accordance with their interests and may conflict with principal interests in order to cover existing profits (discretionary accruals) (Awalia et al., 2014). his has caused earnings quality to decline as happened in several manufacturing companies in Indonesia in 2010 - 2012 which were listed on the stock exchange (Awalia et al., 2014) where litigation risk caused a decline in earnings quality. However, in this research the risk of litigation that occurred did not significantly influence earnings quality where the significance value of Sig. is 0.660 . Therefore, the hypothesis related to litigation risk negatively influences the risk of litigation being rejected because it is not significant.

\subsection{IOS hypothesis on earnings quality.}

The hypothesis related to IOS and earnings quality is that earnings quality get a positive effect from IOS. The test results show IOS has a positive effect on earnings quality where each increase of 1 (one) unit of IOS value then an increase in earnings quality of 0.346 units. This shows that the IOS analyzed can increase the quality of the profits obtained by the company. Myers (1977) argues that there are four common proxies for investment opportunities where indicators are market value to book value, equity, price ratios, and the ratio of capital expenditure to the value of company assets (Lee et al., 2018). In this research, using a proxy used to calculate IOS is the market ratio divided by total equity. Based on the results of hypothesis testing, market value and total equity are both positive or negative. This means that market value and equity give a positive value for IOS or the opposite. If it is positive then IOS can be planned high but if the market value and equity is negative then IOS can be planned low. According to Myers (1997) and Marinda (2014), IOS will affect firm value (Murwaningsari \& Rachmawati, 2017) which also affects earnings quality. In addition, Kallapur and Trombley (2001) argue that IOS policies will affect aspects of corporate finance, corporate capital structure, debt-related contracts, profit policies, compensation contracts, and company-related financial policies (Murwaningsari \& Rachmawati, 2017). Therefore, the value of IOS affects the company's finances which also affects the quality of earnings which in this research is positive. This result is also strengthened by other results where IOS significantly influences the earnings quality where the significance value of Sig. Is $0,000<0.05$. Therefore, hypotheses related to litigation risk positively influence the risk of ligitation being accepted. 
5.3 Hypothesis of the corporate governance moderates litigation risk to earnings quality.

The hypothesis related of the corporate governance moderates litigation risk to earnings quality is the negative influence of litigation risk on earnings quality can be weakened by good corporate governance. Hypothesis testing results indicate that corporate governance moderation on litigation risk has a positive effect on earnings quality where each increase of 1 (one) unit of litigation risk value increases earnings quality by 0.024 units. The application of corporate governance to litigation risk changes the value of litigation risk which was previously negative to change to positive. The implementation of corporate governance can improve company performance in terms of financial, operational, sales, products, resources and investment (Emmanuel \& Toyin, 2019). his is in accordance with several studies conducted on 100 public listed companies in Malaysia (Janggu et al., 2014), chemical manufacturing companies, pharmaceuticals and customer goods in Indonesia (Sofia \& Murwaningsari, 2019), manufacturing companies in Nigeria (Emmanuel \& Toyin, 2019; Omokhudu et al., 2013) all of which implemented corporate governance and experienced an increase in performance that affected earnings management and earnings quality. Unfortunately, the effect on this research is not significant where the significance of sign is. is 0.668 . The factors of corporate governance used in this research are only 1 (one) out of 4 (factors) in corporate governance (Sofia \& Murwaningsari, 2019) namely the number of independent directors divided by the number of commissioners. It is possible that by using only 1 (one) factor, corporate governance has not been able to significantly influence litigation risk, but has not been able to change the quality of earnings that occur. Therefore, the hypothesis related to the negative effect of litigation risk on earnings quality can be strengthened to be positive by good corporate governance rejected.

5.4 Hypothesis of the corporate governance moderates IOS to earnings quality.

The hypothesis related of the corporate governance moderates IOS to earnings quality is the positive influence of IOS on earnings quality reinforced by good corporate governance. The test results show that the corporate governance moderates IOS has a positive influence on earnings quality where the earnings quality will increase by 0.019 units on each increase of 1 (one) unit of IOS value. This shows the IOS value decreases the quality of earnings obtained by companies where from 0.346 to 0.019 . As with litigation risk, the factor of corporate governance that is used is only 1 (one), the independen board of commissioners of the 4 factors of corporate governance (Emmanuel \& Toyin, 2019). Managerial ownership (Kovermann \& Velte, 2019) and managers with superior abilities (Lee et al., 2018) become one of the important factors of good corporate governance that makes a company's performance improve. However, the number of commissioners in this research caused a policy conflict over the planned investment value with the manager. The amount of the investment value affects the value of earnings quality as measured by the ratio of operating cash flows divided by net income. Agency conflict in this research occurs where managers are likely to do high discretionary accruals that also affect IOS and the earnings quality (Wulandari, 2018). Therefore, even if there are superior managers, it must be balanced with other aspects that it can affect the earnings quality company. However, the corporate governance moderates IOS has no effect where the results of testing the significance of the sign. is 0.732 so that IOS which is moderated by corporate governance does not significantly influence earnings quality. Thus, the hypothesis regarding the positive effect of IOS on earnings quality reinforced by good corporate governance is rejected.

5.5 COGH value on earnings quality.

One of the control variables for this research is company growth (COGH). The results of hypothesis testing indicate that if the COGH value rises by 1 (one) unit, there will be an increase in earnings quality of 0.025 units. The effect of COGH on earnings quality is positive with a value of 0.025 . The effect of COGH is very significant where the value of the signification is 0,000 . This is the same as the results of research in manufacturing companies in the country of Ghana (Bour, Asafo, \& Kwarteng, 2019). In manufacturing companies in Ghana, the company's development towards environmental sustainability increased profit margins in a significant positive direction where the company's development variable on profit margins had an effect of $81.3 \%$ compared to other variables.

\section{Conclusion}

The results of the study related to the effect of litigation and IOS risk which are influenced by corporate governance on earnings quality in company of manufacturing in 2013-2016 that entered in the Indonesia Stock Exchange list show that investment opportunity set significantly influences earnings quality, while litigation risk, litigation risk and investment opportunity set which is moderated by good corporate governance are not. In this research, Company growth $(\mathrm{COGH})$ as a control variable is very influence on the magnitude of earnings quality. The board of commissioners, which is one of the factors of corporate governance that moderates litigation risk and the investment opportunity set in this research can change the value of earnings quality but is unable to have a significant effect. Therefore, further research related to other factors of corporate governance on the value of litigation risk and investment opportunity set that affects the quality of earnings is interesting to do. 


\section{Acknowledgments}

Acknowledgments were conveyed to Mrs. Etty Murwaningsari as the supervising lecturers who helped in the making of this journal. Thank you to Trisakti University for providing an opportunity to deepen accounting related knowledge to produce this research journal.

\section{References}

Abdelghany, K. E. (2005). "Measuring the quality of earnings". Managerial Auditing Journal, 20(9), 1001 1015.

Arena, M. P. (2017). "Corporate Litigation and Debt". Journal of Banking and Finance, 1 - 42. doi:10.1016/j.jbankPn.2017.10.005

Arena, M. P., \& Ferris, S. P. (2018). "A global analysis of corporate litigation risk and costs". International Review of Law and Economics, 56, 28 - 41.

Aristiani, R., \& Purwanto, A. (2015). "Pengaruh Kualitas Laba Akutansi Terhadap Efisiensi Investasi Perusahaan Dengan Risiko LIgitasi Sebagai Variabel Moderating (Studi Empiris Pada Perusahaan Manufaktur Yang Terdaftar Di BEI Tahun 20112012)". Diponegoro Journal of Accounting, 4(3), 1 - 11.

Awalia, A., \& Daljono. (2014). "Pengaruh Risiko Ligitasi Terhadap Kualitas Pelaporan Keuangan Dengan Keahlian Hukum Komite Audit Sebagai Variabel Pemoderasi (Studi pada Perusahaan Manufaktur yang Terdaftar di Bursa Efek Indonesia periode 2010-2012)". Diponegoro Journal of Accounting, 3(3), 1 - 13.

Bilal, Chen, S., \& Komal, B. (2018). "Audit Committee Financial Expertise and Earnings Quality: A metaanalysis". Journal of Business Research, 84, 253-270.

Bliss, B. A., Partnoy, F., \& Furchtgott, M. (2017). "Information bundling and securities litigation". Journal of Accounting and Economics, 00, 1 - 24. doi:https://doi.org/10.1016/j.jacceco.2017.11.013

Bour, K. B., Asafo, A. J., \& Kwarteng, B. O. (2019). "Study on the effects of sustainability practices on the growth of manufacturing companies in urban Ghana". Heliyon, 5, 1-8.

Chen, L., Krishnan, G. V., \& Yu, W. (2018). "The relation between audit fee cuts during the global financial crisis and earnings quality and audit quality". Advances in Accounting, 1 - 18. doi:https://doi.org/10.1016/j.adiac.2018.07.007

Chen, S., Bu, M., Wu, S., \& Liang, X. (2014). "How does TMT attention to innovation of Chinese firms influence firm innovation activities? A study on the moderating role of corporate governance". Journal of Business Research, 1 - 9. doi:http://dx.doi.org/10.1016/j.jbusres.2014.11.002

Dechow, P. M., Ge, W., \& Schrand, C. M. (2010). "Understanding Earnings Quality: A Review of the Proxies, Their Determinants and Their Consequences". Accounting Papers University of Pennsylvania, 50(2), 344401.

Emmanuel, O. T., \& Toyin, A. M. (2019). "Corporate Governance as a Strategic Management Tool". Research Journal of Finance and Accounting, 10(14), 111 - 124.

Farinha, J., Mateus, C., \& Soares, N. (2018). "Cash holdings and earnings quality: evidence from the Main and Alternative UK markets". International Review of Financial Analysis, 56, 238 - 252.

Ferracuti, E., \& Stubben, S. R. (2019). "The Role of Financial Reporting in Resolving Uncertainty about Corporate Investment Opportunities ". Journal of Accounting and Economics, 1-25. doi:htpps://doi.org/10.1016/j.jacceco.2019.101248.

Gölgeci, I., Ferraris, A., Arslan, A., \& Tarba, S. Y. (2019). "European MNE subsidiaries' embeddedness and innovation performance: Moderating role of external search depth and breadth". Journal of Business Research, 102, 97 - 108.

Habib, A., \& Hasan, M. M. (2019). "Corporate life cycle research in accounting, finance and corporate governance: A survey, and directions for future research". International Review of Financial Analysis, 16, 188 - 201. doi:https://doi.org/10.1016/j.irfa.2018.12.004

Hassan, E. A. (2017). "The Role of Stock Exchange Efficiency in Earnings Quality: Evidence from the MENA Region ". Research in International Business and Finance, 1 - 32 doi:http://dx.doi.org/doi:10.1016/j.ribaf.2017.07.097

Iqbal, K., \& Kakakhel, S. J. (2016). "Corporate Governance and its Impact on Profitability of the Pharmaceutical Industry in Pakistan". Journal of Managerial Sciences, X(1), 73 - 82.

Janggu, T., Darus, F., Zain, M. M., \& Sawani, Y. (2014). "Does good corporate governance lead to better sustainability reporting? an analysis using structural equation modeling ". Procedia - Social and Behavioral Sciences 145, 138 - 145.

Jin, J. Y., Kanagaretnam, K., \& Liu, Y. (2018). "Banks' funding structure and earnings quality". International Review of Financial Analysis, 1 - 60. doi:10.1016/j.irfa.2018.08.009

Kovermann, J., \& Velte, P. (2019). "The Impact of Corporate Governance on Corporate Tax Avoidance - A Literature Review". Journal Pre-proof, 1-68. doi:https://doi.org/10.1016/j.intaccaudtax.2019.100270

Lee, C. C., Wang, C. W., Chiu, W. C., \& Tien, T. S. (2018). "Managerial ability and corporate investment 
opportunity". International Review of Financial Analysis, 57, 65 - 76.

Mazur, M., Salganik-Shoshan, G., Walker, T., \& Wang, J. (2018). "Proximity and litigation: Evidence from the geographic location of institutional investors". Journal of Financial Markets, $1 \quad-15$. doi:https://doi.org/10.1016/j.finmar.2018.05.002

Murwaningsari, E. (2009). "Hubungan Corporate Governance, Corporate Social Responsibilities dan Corporate Financial Performance Dalam Satu Continuum ". Jurnal Akuntansi dan Keuangan, 11(1), 30 - 41.

Murwaningsari, E., \& Rachmawati, S. (2017). "The Influence of Capital Intensity and Investment Opportunity Set toward Conservatism with Managerial Ownership as Moderating Variable ". Journal of Advanced Management Science, 5(6).

Mustapa, I. R., Ghazali, N. A. M., \& Mohamad, M. H. S. (2014). "The moderating influence of organizational capacity on the association between corporate governance and corporate performace". Procedia - Social and Behavioral Sciences, 164, $76-83$.

Nafisah, L., \& Meiranto, W. (2017). "Pengaruh Karakteristik Perusahaan Terhadap Pengungkapan Modal Intelektual Dalam Prospektus IPO". Diponegoro Journal of Accounting, 6(3), 1 - 11.

Naula Oktaviani, R., Nur, E., \& Ratnawati, V. (2015). "Pengaruh Good Corporate Governance Terhadap Kualitas Laba Dengan Manajemen Laba Sebagai Variabel Interventing (Studi Empiris Pada Perusahaan Manufaktur Yang Terdaftar Di Bursa Efek Indonesia Tahun 2009-2012)". Jurnal Ekonomi, Manajemen dan Akutansi I Vol. 25 No. 2 Desember 2015, 25, 96-115.

Nguyen, H. T., Phan, H. V., \& Sun, L. S. (2018). "Shareholder litigation rights and corporate cash holdings: Evidence from universal demand laws". Journal of Corporate Finance, 1 - 73. doi:10.1016/j.jcorpfin.2018.08.002

Omokhudu, O. W., Stephen, R. F. C. C., \& (Ph.D), K. A. A. (2013). "The Impact of Corporate Governance on the Performance of Manufacturing Firms in Nigeria". International Journal of Science and Research (IJSR). doi:10.21275/ART20161412

Peda, P., \& Vinnari, E. (2019). "The Discursive Legitimation of Profit In Public-Private Service Delivery". Critical Perspectives on Accounting, 1(1), 1 - 22.

Rodriguez-Fernandez, M. (2016). "Social responsibility and financial performance: The role of good corporate governance". BRQ Business Research Quarterly, $19, \quad 137 \quad$ - 151. doi:http://dx.doi.org/10.1016/j.brq.2015.08.001

Septiyani, G., Rasyid, E., \& Tobing, E. G. (2017). "Faktor-faktor Yang Mempengaruhi Kualitas Laba Pada Perusahaan Industri Dasar dan Kimia Yang Terdaftar Di Bursa Efek Indonesia Periode 2012 - 2015". fundamental management journal, 2, 70 - 79.

Sofia, I. P., \& Murwaningsari, E. (2019). "The Role of Corporate Diversification, Capital Structure Determinant, And Structure of Ownership on Earning Management with Information Asymmetry as Moderating Variable ". Research Journal of Finance and Accounting, 10(14), 45 - 51.

Thraya, M. F., Lichy, J., Louizi, A., \& Rzem, M. (2019). "High-tech acquirers and the moderating role of corporate governance". Journal of High Technology Management Research, $1 \quad$ - 12. doi:https://doi.org/10.1016/j.hitech.2019.100354

Todorovic, I. (2013). "Impact Of Corporate Governance On Performance Of Companies ". Montenegrin Journal of Economics, 9(2), 47 - 53.

Wati, G. P., \& Putra, I. W. (2017). "Pengaruh Ukuran Perusahaan, Leverage dan Good Corporate Governance Pada Kualitas Laba ". E-Jurnal Akuntansi Universitas Udayana, 19(1), 137-167.

Wulandari, S. (2018). "Pengaruh Pertumbuhan Laba, Size, Leverage Investment Opportunity Set, Dan Good Corporate Governance Terhadap Kualitas Laba (Studi Empiris Perusahaan Manufaktur terdaftar di Bursa Efek Indonesia Periode 2013-2015)". Fakultas Ekonomi dan Bisnis, 1(1), 1 - 21.

Zhang, M. (2018). "Conditional Pricing of Earnings Quality". Finance Research Letters, 1 - 18. doi:https://doi.org/10.1016/j.frl.2018.10.015 